\title{
Influence of Exercise Model Load on Superior Limb to Enhancement Ability Swimming Butterfly Style 50 meters
}

\author{
Leni Asril*, Witarsyah, Umar \\ Faculty of Sport Science \\ Universitas Negeri Padang \\ Padang, Indonesia \\ leni.asri193@gmail.com
}

\begin{abstract}
This study aimed to determine the effect of weight training to increase the ability of style swimming 50meter butterfly swimming student specialization FIK UNP. This research is quasi-experimental. The population in this study are all students of specialization pool JulyDecember semester of 2014/2015, amounting to 10 students. The results of that study are a significant effect of weight training on the ability of the butterfly stroke swimming 50 yards, an average of 66.11 seconds to 56.78 seconds, in which the test results mean difference (t-test) obtained $t_{\text {hit }} 8.537$ $>2.306 t_{\text {tab. }}$
\end{abstract}

Keywords - weight training, swimming ability butterfly 50 meters

\section{INTRODUCTION}

"Swimming is one branch of aquatic sports which is now popular in the middle - the middle The development of swimming in sports communities Indonesia is increasingly accepted and loved by the community, even at school school This swimming branch has become there are subjects which must be taught by Physical Education teachers"[1].

The butterfly swimming style is one of the styles used as lecture material in the swimming pool specialization of the FIK-UNP Training Department. In the butterfly style technique, many factors affect the ability to produce maximum swimming speed, including limb muscles, arm muscles, speed, infrastructure and nutritious food. Accordingly, the researchers assume that physical condition is an important element in swimming because swimming is an activity that requires complex movements.

Based on observations at the time of swimming specialization lectures, in the $50 \mathrm{~m}$ butterfly-style swimming there were still many students of FIK UNP coaching, from the beginning the student pool was good and gradually slowed down and the student's swimming movements became irregular to continue swimming up to a distance of 50 meters. In addition, the exercise that was carried out was not regular, after finishing swimming there was no exercise on another day when not swimming class. This certainly affects the physical condition of students. Physical conditions that are not good impact on the strength of muscle strength that can affect the rate of swimming $50 \mathrm{~m}$ butterfly force in obtaining the best time.

From monitoring the phenomena that occur in the field during lectures and corroborated by data obtained from lecturers who teach swimming in the Department of Training FIK-UNP, there is a strong suspicion that the inability of students to do a $50 \mathrm{~m}$ butterfly-style swimming is dominated by the conditions of the strength of the muscles that are owned by the students. in accordance with expectations. This is evidenced when the appearance of the ability to swim $50 \mathrm{~m}$ butterfly style, often found problems in the speed and strength of pedaling so that arm movements carried out repeatedly with a long time can not maintain to get a good speed.The data can be seen in the table below.

Table 1. student learning outcomes 50 meter butterfly-style swimming.

\begin{tabular}{|c|c|c|c|c|c|}
\hline No & Name & $\begin{array}{c}\text { Time } \\
\text { (second) }\end{array}$ & No & Name & $\begin{array}{c}\text { Time } \\
\text { (second }\end{array}$ \\
\hline 1. & $\begin{array}{c}\text { Rangga adi } \\
\text { putra }\end{array}$ & 66 & 6. & $\begin{array}{c}\text { Harry } \\
\text { febrian } \\
\text { di }\end{array}$ & 63 \\
\hline 2. & Dio tofik & 65 & 7. & $\begin{array}{c}\text { Harifan } \\
\text { di }\end{array}$ & 79 \\
\hline 3. & $\begin{array}{c}\text { Teguh } \\
\text { andika putra }\end{array}$ & 70 & 8. & $\begin{array}{c}\text { Bobby } \\
\text { andrian }\end{array}$ & 78 \\
\hline 4. & $\begin{array}{c}\text { Sahdi arifin } \\
\text { Riko } \\
\text { andriant } \\
\text { o }\end{array}$ & 79 \\
\hline 5. & $\begin{array}{c}\text { Aldi tantra } \\
\text { yanto }\end{array}$ & 76 & 10. & $\begin{array}{c}\text { Sriwah } \\
\text { yuni }\end{array}$ & 81 \\
\hline
\end{tabular}

Source: Specialized swimming lecturer

Based on the explanation above, the researchers suspect that the problem of the inability of FIK-UNP Department of Coaching students to do 50 meter butterfly-style swimming is caused by ineffective and irregular training that affects physical condition, especially the condition of endurance of arm muscle strength. arm motion to perform the task of motion that burdens the arm muscles in quite a long time. Factor arm motion in the 50-meter butterfly-style swimming 
is the dominant motion to get optimal speed and the smallest time limit.

An increase in the endurance component of arm muscle strength can be done with a variety of training methods, including through weight training. weight training (weight training) is a form of exercise that uses media to support the process of training with the aim to improve fitness, muscle strength, speed, muscle tightening, and muscle hypertrophy, in the butterfly swimming 50 meters can be done in forms of weight training such as: bench press, pulley row, pull down, and shoulder press[2].

In order for the exercise to be carried out properly, it is necessary to practice systematically and gradually, especially on the ability of FIK-UNP Coaching students, which relate to physical condition factors in swimming in order to be improved, so that sports achievements will be more easily achieved.

Seeing the importance of weight training and the problems that occur in the ability to swim $50 \mathrm{~m}$ butterflystyle swimming in sports coaching students, researchers are interested and encouraged to conduct research on the effect of weight training models on superior limbs to increase the ability to swim $50 \mathrm{~m}$ butterfly-style swimming specialization Faculty of Sport Science, Padang State University.

\section{Butterfly Swimming Capability}

ability is how one can get the quality of skilled action. In this case, the ability of a swimmer can be seen from the swimming skills of the butterfly with the fastest mileage achieved with a stopwatch meter measured in units of time.

The ability to swim the butterfly style is competed starting from the Provincial Sports Week (PORPROV), Regional Sports Week (PORWIL), National Sports Week (PON), to the Regional (SEA Games) and International (Asian Games and Olympic Games) levels from a distance 50 meters, 100 meters, 200 meters with the ability to use a maximum speed, to get the fastest time measured in units of time.

\section{Weight Training}

weight training is weight training carried out systematically using weights as a tool to increase muscle strength to improve the physical condition of athletes[3]. Weight training can be done using weight from one's own weight (internal load) or using external weights that are free weights or weight machines (gym machines). The form of exercise is very numerous and varies according to the purpose of the exercise and the imposition of muscles.

In principle, to be able to increase muscle strength and endurance, an exercise is applied, because with exercise the muscles will be able to contract so that there will be changes in muscle function. some exercises that can be used in exercising muscles, especially the upper body muscles related to swimming are as follows:

\section{a. Bench Press Weight Training}

Bench press is a form of exercise with the aim of increasing the strength of the arm muscles. This form of exercise has the characteristics of movement where the arm is moved pushing the object (load) upward with the position of the body below / lying straight. , to increase strength, power, and muscular endurance. The results obtained from using weight training is the ability of the muscles to be better than before the exercise was done. The purpose of bench press exercises in this study is to increase the power of the muscles of the upper body, namely: deltoid, upper pectoralis major, trapezius, latissimus dorsi, and triceps, all of which function to move the arm. The way to do bench press exercises is as follows: 1) Load on the chest with both hands holding the shoulder barbell as wide as a shoulder, 2) Attitude of both feet in line and open about shoulder width apart, 3) Push the barbell upward until the arms are straight, then lower the barbell back on the chest.

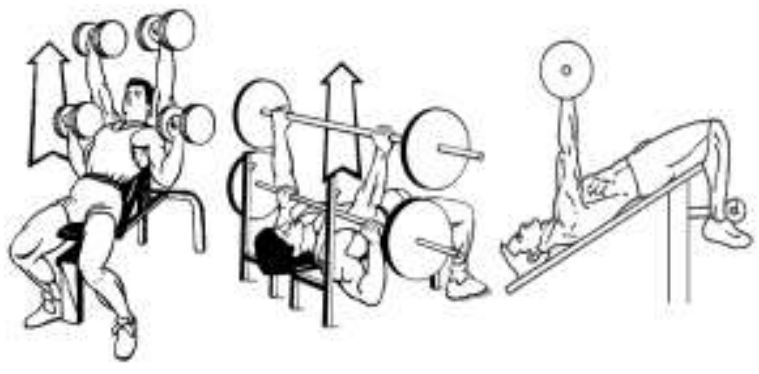

Figure 1: Bench Press Training (Source: Baechle, Thomas R. 2003. Weight Training. Razi Siregar Translation. Jakarta. PT Raja Grafindo: 177)

\section{b. Shoulders Press Weight Training}

shoulder press training is a form of exercise that is useful for training the entire set of muscles used to press with the arm[2]. Shoulder press exercises are a form of exercise to train the muscles of the arms / hands that function as muscular deltoid muscles (triangular muscles), musculus triceps (three-headed arm muscles), trculzius muscle (veil muscles). These muscles play a major role in supporting the arms that get weight training and if carried out in a systematic and regular exercise program procedure it is hoped that physiology and hypertropy of the muscles in the segment can contribute to increasing arm/hand muscle strength.(Www.sport.journal. wordprees.com)

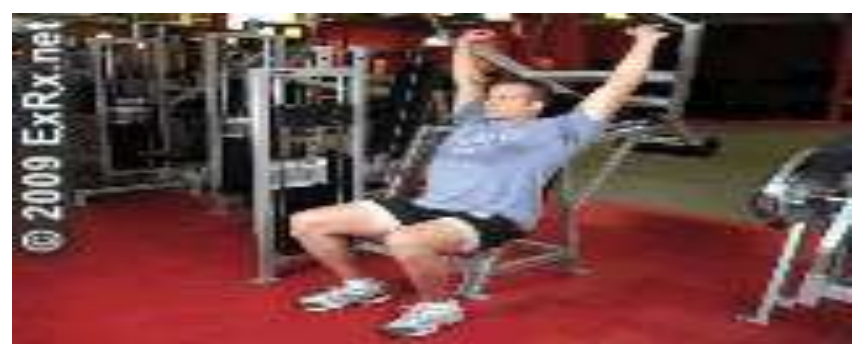

Figure 2: Shoulders Press Exercise

(Source of ExRx. Net 2009).

\section{c. Pull-Downs Weight Training}

Pull down exercises are a type of exercise that focuses on forming the back muscles where the main muscles that work 
are the latissimus dorsi muscles, the teres major and posterior deltoid muscles.
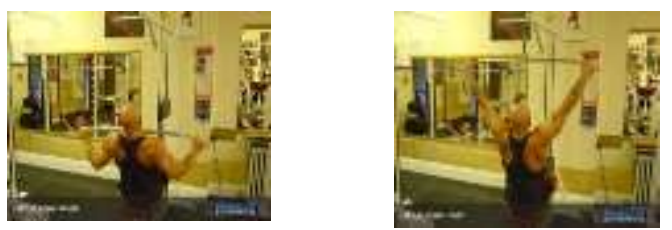

Figure 3: Pull-Downs Exercise (Source of ExRx. Net 2009)

\section{d. Pulley Row Weight Training}

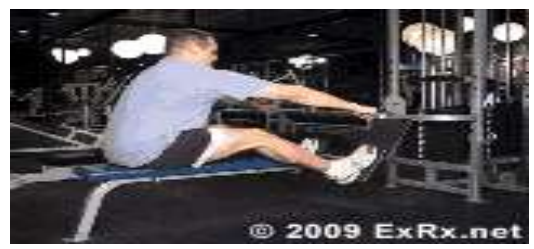

Figure 4: Pulley Row Exercise (ExRx. Net source 2009)

\section{RESEARCH METHODS}

This research is a type of quasi-experimental research. "Quasi-experimental research is research approaching a real experiment where it is not possible to control, manipulate all relevant variables"[4]. In view of the location of the study, this study is included in the field of experimental research.

This research is descriptive. Method used in this research is quantitative. Quantitative research method is a research method that based on positive philosophy and used to observe in population or certain sample. Collecting data use research instrument, data analysis in quantitative/statistic form with the purpose is to test the hypothesis [5].

This research design uses one group pretest postest design. For more details, the research design can be illustrated through the chart below. (UNP Statistics Course Team Book).

\begin{tabular}{|c|c|c|}
\hline \\
\hline \multicolumn{3}{|c|}{$\begin{array}{c}\text { Information: } \\
P\end{array}$} \\
\hline \multicolumn{3}{|r|}{ Samples 1} \\
\hline Pretest & : & Initial Test \\
\hline $\mathrm{P}$ & : & Treat (weight training) \\
\hline Postest & : & Final Test \\
\hline
\end{tabular}

The population in this study were students who took specialization swimming courses with the lecturer Advisors Drs. Maidarman, M.Pd section code 51811 who attended the lectures in the July - December semester of the 2014/2015 academic year Department of Coaching at the Faculty of Sports Science UNP. Based on the preliminary study, 10 students were enrolled (9 sons and 1 daughter). This research will be carried out in the lotus swimming pool on J1 .atang Kampar Gor H. Agus Salim Padang for 18 meetings, 3 times a week and includes the initial test and final test. The sampling technique in this study is purposive sampling. The sample in this study were 9 male students, because there were only one female student and the sample was homogeneous.

Since the data needed in this study is primary data, the data collection was carried out by carrying out the test, the test used is the ability to swim 50 meters butterfly style, aiming to measure the ability of swimming speed by taking time to swim speed, before the test is done first prepared data collection steps, exercise programs, test implementation and matters relating to data collection and measurement.

1. Tools and Equipment Use Data Collection

a. Test post to record the initial test and the final test (pretest-posttest)

b. Stopwatch

c. Whistle

d. Attendance book

e. Pen

2. Test Implementation Officer

a. Before the test, first be given directions and instructions in accordance with the provisions of the test that will be used.

3. Test Implementation

a. Start is done on the starting beam with the body bent position.

b. Position both legs straight and slightly opened, both hands / fingertips touching the floor of the starting beam

c. After the start signal is released by blowing the whistle the start starts, the stopwatch is started and stopped when the teste reaches the finish line.

4. Logger

The data recorded as a result of the test is the time taken by students starting from the "was" signal and after the whistle sounded to finish. The time taken from this test is called the initial test, then students are given treatment for 18 times face to face, after the treatment the student is given the final test, the time taken from both tests is recorded in the test results to be processed and analyzed.

To be able to measure the swimming speed time, starting with the testee taking a standing position on the starting beam, by taking the position of the bending body, with the position of both fingers touching the start beam, after the start signal is released by blowing the whistle, the testee is ready to do start, stopwatch that is run and stopped when the testee reaches the finish line. Assessment: the testee sprints swimming $50 \mathrm{~m}$ butterfly style with 1 repetition, when the testee reaches the finish line both hands must simultaneously touch the edge of the pool wall touch both palms simultaneously while underwater or above the water surface, vice versa what if the testee touches the finish line of the edge of the pool wall with one hand then it is declared disqualified or failed, from the one repetition the best time is taken. 
There are also implementation steps consisting of:

\section{Initial Test}

Before weight training is done, then the initial 50 meter butterfly style swimming test is given which aims to determine the initial abilities of the person / student being tested.

\section{Treatment}

The treatment was given 18 meetings ( 3 times a week). A more complete description can be seen in the exercise program in the appendix.

3. Final Test

After the treatment is given 18 meetings, a final test is carried out on all the samples that have been tested, from the final test data it can be seen the increase in training achieved by the samples that have been tested.

Before the data is obtained, first prepare the supporting factors to obtain data. Before getting a sample, researchers conducted observations and requested information from teaching staff about the number of students and existing sports facilities. After getting the information and observing then the researcher consulted with the supervisor and asked for a letter of introduction for the research permit addressed to the teaching staff who taught specialized swimming courses in the lotus swimming pool at Jl.Batang Kampar near GOR H.Agus Salim Padang to conduct research.

In accordance with the problems and research objectives outlined earlier, that the research carried out intends to find information about the effect of weight training on the ability of the $50 \mathrm{~m}$ butterfly swimming force to specialize in swimming students. To obtain the required data, systematic steps are first arranged, namely as follows:

1. Make a research proposal

2. Determine the research schedule

3. Request a research permit from the Dean of FIK and the Department, and the place of research

4. Preparing expert assistants and supervisors to expedite research for data collection.

5. Prepare the tool and prepare data content format.

Data description and hypothesis testing in this study can be processed using descriptive and inferential statistics with the formula $t$ 'bound sample test formula. This matter

According to the type of research that researchers do. Before the data is processed, the normality test is done first because the ' $\mathrm{t}$ ' test can only be done to test the mean difference of two samples taken from one normal population.

\section{RESULTS AND DISCUSSION}

\section{Description of the data}

The description of the data from this research is in the form of the initial test data (pre test) and the final test (post test) swimming 50 meter butterfly style. In the initial test (pre test) conducted on 9 people the sample obtained the highest score of 74 seconds and the lowest score of 52 seconds, the average score the average is 66.11 seconds. After being given the treatment of the 9 samples, it is certain that weight training is bench press, shoulders press, pull down and pulley row where at each meeting the intensity of the training load is increased, this weight training program can be seen in appendix 2 page70, then a final test (post) test) swimming 50 meters butterfly style then obtained the largest score of 62 seconds and the smallest score of 49 seconds, the average score is 56.78 seconds.

Table 2. Frequency distribution of pre-test and post-test results

50 meter butterfly-style swimming ability.

\begin{tabular}{|c|c|c|c|c|c|}
\hline \multirow[b]{2}{*}{$\begin{array}{c}\text { Interval } \\
(\mathrm{sc})\end{array}$} & \multicolumn{2}{|c|}{$\begin{array}{c}\text { Frequency pre } \\
\text { test }\end{array}$} & \multicolumn{2}{|c|}{$\begin{array}{c}\text { Frequency post } \\
\text { test }\end{array}$} & \multirow[b]{2}{*}{$\begin{array}{c}\text { Categ } \\
\text { ory }\end{array}$} \\
\hline & $\begin{array}{l}\text { Absolut } \\
\text { e (Fi) }\end{array}$ & $\begin{array}{c}\text { Relat } \\
\text { ive } \\
(\%)\end{array}$ & $\begin{array}{c}\text { Absol } \\
\text { ute } \\
\text { (Fi) }\end{array}$ & $\begin{array}{l}\text { Relati } \\
\text { ve }(\%)\end{array}$ & \\
\hline$<55$ & 1 & 11,11 & 5 & 55,56 & $\begin{array}{l}\text { Very } \\
\text { Good }\end{array}$ \\
\hline $56-64$ & 3 & 33,33 & 4 & 44,44 & Good \\
\hline $65-81$ & 5 & 55,56 & 0 & 0 & $\begin{array}{c}\text { Avera } \\
\text { ge }\end{array}$ \\
\hline $82-89$ & 0 & 0 & 0 & 0 & Poor \\
\hline$>90$ & 0 & 0 & 0 & 0 & $\begin{array}{l}\text { Very } \\
\text { Poor }\end{array}$ \\
\hline Total & 9 & 100 & 9 & 100 & \\
\hline
\end{tabular}

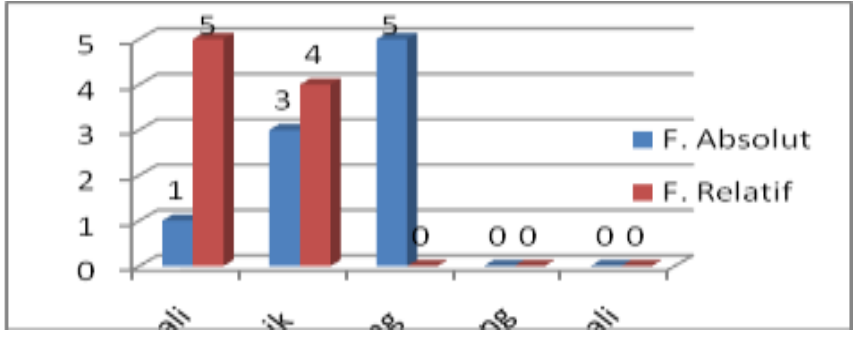

Figure 5

Histogram results of pre-test and post-test of the ability to swim butterfly style 50 meters.

The information obtained in the frequency distribution table and the histogram of the bar above is the assessment the researcher made himself based on the scores obtained from the initial and final ability of the 50 meter butterflystyle swimming from the research sample with a five-scale formula. So the assessment category is only specific to the 50 meter butterfly style swimming assessment for the research sample of researchers. Based on the frequency distribution table in table 2 and the stem histogram in Figure 6 for the pre-test data of the 50 meter butterfly style swimming ability obtained from 9 swimmers, 1 person $(11.11 \%)$ has a 50 meter butterfly style swimming ability with a very good category, 3 people $(33.33 \%)$ had a 50 meter butterfly swimming ability level with a good category, 5 people $(55.56 \%)$ had a 50 meter butterfly style swimming ability with a medium category, and for the ability to swim in the butterfly style 50 meters the category is less and less than $0 \%$ of the sample is owned. Based on the average score of the 50 meter butterfly style swimming ability level obtained was 66.11 seconds, it can be concluded that the 50 
meter butterfly style swimming ability level before being given weight training was in the moderate category.

Based on table 2 frequency distribution and stem histogram in Figure 6 for the post test data, the ability to swim 50m butterfly style results obtained from 9 swimmers, 5 people $(55.56 \%)$ have the ability to swim $50 \mathrm{~m}$ butterfly style swimming with category very well, 4 people $(44.44 \%)$ had a 50 meter butterfly swimming ability level with a good category and for the moderate category 50 meter butterfly swimming ability, $0 \%$ and less were $0 \%$ owned by the sample. Based on the average score of the 50 meter butterfly-style swimming ability level obtained was 56.78 seconds, it can be concluded that the 50-meter butterflystyle swimming ability level after being given weight training is in the good category.

\section{Testing Requirements Analysis}

Before testing the proposed hypothesis, it first tests the data analysis requirements, namely the normality test of each data from the variable. Data normality test of the variables is done by using the Kolmogorov-Smirnov test which is assisted by using SPSS 15 and accepting or rejecting the normal decision whether or not the data is set at a significant level $\alpha=0.05$.

The results of the normality test calculations can be seen in appendix 4 page 89 . Based on these results it can be seen that the significant value of the pre-test data probability is 0.578 and the post test is 0.766 which is greater than the significance of $\alpha 0.05$. Therefore, it can be concluded that the data of the two variables in the study this forms the normal distribution.

\section{Hypothesis Testing}

The hypothesis proposed is that there is a significant influence of weight training on the ability to swim $50 \mathrm{~m}$ butterfly style. Based on the comparative analysis with the mean different test formula ( $t$ test) conducted, the results of the analysis of the mean different test ( $t$ test) are obtained as follows.

Table 3. Summary of the results (t-test) of the effect of free training on the swimming ability of the 50-meter butterfly force.

\begin{tabular}{|c|c|c|c|c|c|}
\hline \multirow{2}{*}{$\begin{array}{c}\text { Dk= } \\
(\mathrm{N}-1)\end{array}$} & \multicolumn{2}{|c|}{$\begin{array}{c}\text { Average } \\
\text { (second) }\end{array}$} & $\begin{array}{l}\text { Pre } \\
\text { test }\end{array}$ & $\begin{array}{c}\text { Post } \\
\text { test }\end{array}$ & $\mathbf{t}_{\text {tab }}$ \\
$\begin{array}{c}\alpha= \\
0,05\end{array}$ & Conclusion \\
\hline 7 & 66,11 & 56,78 & 8,537 & 2,306 & Signifikan \\
\hline
\end{tabular}

Information :

thit $=$ different coefficient test mean count

$\mathrm{ttab}=$ different coefficient test mean table

The result of the analysis of the mean difference test states that there is a significant influence of weight training on the ability to increase the swimming ability of the butterfly 50 meter. This is based on the results of the analysis of the mean different test, which is obtained thit8,537> ttab2.306 at the significance level $\alpha=0.05$, it can be concluded that there is a significant effect of weight training on the increase in swimming ability of the 50 meter butterfly style.

\section{CONCLUSIONS AND SUGGESTION}

\section{Conclusions}

Based on the results of the study it can be concluded that there is a significant influence of weight training on the swimming ability of the butterfly style 50 meters, from an average of 66.11 seconds to 56.78 seconds (thit8,537> ttab 2,306).

\section{Suggestions}

Based on the conclusions above, the researcher can provide the following suggestions:

a. For butterfly-style swimming trainers it is recommended to choose the form of weight training in order to improve the butterfly-style swimming ability

b. It is recommended that athletes with butterfly-style swimming choose weight training such as bench press, shoulders press, pulldown and pulley row for butterflystyle swimming abilities.

c. Researchers who want to do a more in-depth study of forms of exercise that can improve the ability to swim in the butterfly style are advised to choose other forms of exercise and compare them with weight training.

\section{Research Limitations}

In carrying out this experimental study researchers are aware of the limitations that arise, including:

a. The research sample is not an athlete but a student. Overall the sample lives with parents, this causes researchers to have difficulty monitoring the sample's activities while out of training hours. The facts in the field that the researchers found were that some of the samples experienced fatigue, drowsiness and so on while attending the exercise. Researchers suspect they stayed up all night or did not get a balanced nutritional intake with the treatment that researchers gave to the sample. So in this case researchers are often faced by problems about the saturation and laziness of the sample to follow the training program that researchers arrange. Therefore, researchers get a little obstacle when some of the sample people experience the boredom following the exercise, this has an impact on their motivation to run an exercise program that the researcher has composed.

b. With the lotus pool situation which is always crowded by visitors, this has an impact on the concentration of the sample in undergoing training seriously and fully committed. 


\section{REFERENCES}

[1] D. A. Putra and W. Witarsyah, "Pengaruh Latihan Dayatahan Kekuatan Otot Lengan dan Otot Tungkai Terhadap Kecepatan Renang Gaya Dada 50 Meter", jpdo, vol. 2, no. 1, pp. 51-56, Dec. 2019.

[2] D.P. Irianto. "Bugar dan Sehat dengan Berolahraga". Yogyakarta: CV. Andi Offset. 2004, pp. 37.

[3] N. Ahmad. "Pengaruh Latihan Circuit Weihgt Training Terhadap Kekuatan Dan Daya Tahan Otot" (www.sport_journal.wordprees.com/2009/10/02) diakses tanggal 3 Januari 2013. 2009

[4] R. Aswandi. "Pengaruh Latihan Push-up dan Pull-up Terhadap Kemampuan Chestpass Bolabasket Siswa Sekolah". 2008, pp. 25.

[5] Zulbahri. Setiawan, M. N. A. "Increasing Aerobic Durability Skill by Practicing Extensive Interval Method for Volleyball Athlete in Rokan Hulu Regency". Applied Science and Technology, 2(1).pp. 128-131. Feb 2018. 